\title{
Rancang Bangun Pengendali Rumah Jarak Jauh Terintegrasi Berbasis Mikrokontroler Menggunakan Jaringan Internet Memanfaatkan Framework Openhab
}

\author{
Yurindra \\ STMIK Atma Luhur Pangkalpinang \\ J1. Jend. Sudirman, Selindung, Pangkalpinang \\ Kepulauan Bangka Belitung \\ yurindra@atmaluhur.ac.id
}

\author{
Joko Supriyanto \\ Teknik Informatika STMIK Atma Luhur \\ Jl. Jend. Sudirman, Selindung, Pangkalpinang \\ Kepulauan Bangka Belitung \\ fhico25@gmail.com
}

\begin{abstract}
Abstrak - Tujuan dari penulisan ini adalah untuk menghasilkan karya nyata, berupa sistem pengendali perangkat elektronik rumah tangga yang terintegrasi berbasis internet yang bisa di aksess oleh berbagai perangkat dengan kendali jarak jauh. Metode yang di gunakan dalam pembuatan aplikasi pengendali rumah jarak jauh terintegrasi berbasis mikrokontoler menggunakan jaringan internet memanfaatkan framework Openhab penelitian ini terdiri dari beberapa tahap yaitu , studi pustaka, metode analisis, metode perancangan, dan implementasi. Hasil yang di capai adalah memberi kemudahan bagi pengguna smartphone dan pc yang terkoneksi dengan internet untuk mengendalikan perangat elektronik dan sistem kemanan pada rumah atau kantor untuk meningkatkan efesiensi, kenyamanan dan kemanan pemilik rumah, dimana rangkaian ini bekerja ketika pengguna atau pemilik rumah ingin mengakses informasi pada rumahnya dimana setiap komponen seperti arduino, Ethernet sheld, Orange Pi yang bertidak sebagi server akan mengumpulkan data yang di dapat dari sensorsensor dan kemudian di kirimkan kepada pengguna melalui menu intrface OpenHab. Kesimpulan yang di dapat adalah peralatan ini telah di uji dan dapat di gunakan dalam mengendalikan rumah jarak jauh yang terintegrasi dimana pemilik rumah dengan mudah mengendalikan peralatan elektronik pada rumah yang bisa di aksess melalui berbagai perangkat baik itu pc maupun smartphone
\end{abstract}

Kata Kunci : Smart Home, Home Automation, Internet of Things, OpenHab, Rumah Pintar.

\section{Pendahuluan}

Pengaktifan peralatan elektronik yang berada di dalam rumah biasanya perlu menekan suatu tombol atau harus melakukan sesuatu secara manual. Hal ini kadang membutuhkan penggunaan waktu yang tidak efisien. Penggunaan saklar juga membutuhkan sebuah aksi dari manusia untuk menuju ke tempat saklar itu berada yang membutuhkan waktu dan tenaga lebih. Ditambah lagi apabila kondisi manusia kurang memungkinkan untuk melakukan aktifitas fisik seperti bagi para difabel atau manusia dalam kondisi lelah atau sakit, hal tersebut merupakan sesuatu yang sulit dilakukan dan apabila pengguna sedang berada di luar kota maka sulit untuk mematikan peralatan listrik dan memantau keadaan rumah dalam kondisi aman atau tidak selain itu menyalanya listrik akan terbuang sia-sia. dalam hal ini ingin mengembangkan perangkat pengendalian elektronik yang terintegerasi dengan sistem keamanan rumah secara jarak jauh. Dengan memperhatikan kondisi manusia yang telah disebutkan, maka dilakukan pengembangan terhadap kemudahan penggunaan peralatan dalam rumah yang biasa disebut rumah cerdas (smart home). Pada pengembangan sistem smart home, masukan sebagai perintah untuk unit kontrol smart home didasarkan pada sensor sehingga dihasilkan sistem otomasi dalam pengendalian peralatan rumah dengan kontrol yang sangat kecil atau bahkan tidak melakukan kontrol sama sekali dari user atau manusia penghuni rumah. Apabila manusia masih dapat melakukan kontrol terhadap peralatan rumah, maka pengendalian peralatan dapat disesuaikan dengan kebutuhan dan keinginan manusia itu sendiri tanpa harus selalu bergantung dari hasil pembacaan sensor. Untuk itu dilakukan penelitian untuk mendukung unit kontrol smart home yang merupakan penerapan konsep webbased konsep tersebut telah membawa dampak positif dalam kehidupan manusia.Pengolahan aplikasi web based telah banyak digunakan dalam berbagai aplikasi. Sebagai contoh, aplikasi-aplikasi kantor multi user dan banyak lagi.

\section{TINJAUAN PUSTAKA}

\section{A. Tinjauan Studi}

Penelitian yang dilakukan oleh Widiatmoko, dengan judul Rancangan Sistem Otomatisasi Perangkat Elektronis Rumah Berbasis Internet of Things Memanfaatkan Framework Soulis dan OpenHab, penelitian ini menawarkan salah satu solusi pengelolaan perangkat elektronis rumah dengan sistem otomatisasi. Sistem ini dibangun pada perangkat Arduino Mega dengan memanfaatkan framework Souliss dalam pemrogramannya. Dalam sistem yang dibangun, perangkat elektronis akan memiliki smart mode agar perangkat elektronis dapat terkelola sesuai dengan kebutuhan. Dengan bantuan OpenHAB, pengelolaan perangkat elektronis dapat dilakukan melalui smartphone. Komunikasi antara Arduino dan smartphone berjalan pada Local Area Network dengan 
bantuan perangkat access point. Dengan sistem yang dirancang, pengguna dapat mengelola dan memantau perangkat elektronis rumah dengan smartphone atau komputer yang dimiliki. Dengan pengelolaan yang baik maka energi listrik yang digunakan akan lebih efisien[1].

\section{Metode Penelitian}

\section{A. Metode Pengumpulan Data}

\section{1) Studi Kepustakaan}

Pada tahap ini dilakukan untuk mengambil beberapa data yang berasal dari berbagai sumber seperti buku, skripsi, jurnal ilmiah dan internet dimana isi dari sumber-sumber tersebut dijadikan suatu referensi dan acuan dalam penulisan ini.

\section{B. Analisa Sistem}

Analisis sistem dilakukan untuk memberikan arahan dan menentukan tahap proses pengerjaan selanjutnya dalam hal penentuan kebijakan. Adapun tahapan yang akan dilakukan dalam analisa sistem ini adalah sebagai berikut:

1. Penyelesaian masalah, tahapan ini memberikan solusi dari permasalahan yang sedang di hadapi .

2. Identifikasi Kebutuhan, tahapan ini melakukan peninjauan untuk apa saja yang di perlukan

3. Analisa Kebutuhan, tahapan ini melakukan analisa perangkat keras dan perangkat lunak yang dibutuhkan.

4. Analisa Sistem Berjalan, tahap ini dilakukan untuk mengetahui sistem atau proses yang sedang berjalan sekarang dan digambarkan dalam activity diagram dan usecase diagram.

5. Analisa Kelayakan, tahapan ini melakukan studi kelayakan terhadap sistem dan teknik yang digunakan.

\section{Perancangan Sistem}

Tahap Perancangan Sistem adalah merancang sistem secara rinci berdasarkan hasil analisa sistem yang ada, sehingga menghasilkan model sistem baru yang diusulkan. Adapun tahapan yang akan dilakukan dalam perancangan sistem ini adalah sebagai berikut:

1. Analisis Aplikasi Pengendali Rumah Jarak Jauh Terintegrasi, tahapan ini bertujuan untuk mengetahui bagaimana prosess sistem yang baru bekerja digambarkan dalam activitiy diagram dan usecase diagram.

2. Perancangan Sistem Kerja, tahapan ini menjelaskan perancangan sistem kerja, yang digambarkan melalui Deployment diagram dan Blok diagram.

3. Perancangan Perangkat Keras, tahapan ini akan memberikan gambaran rangkaian sistem yang akan di gunakan digambarkan melalui komponen diagram dan activitiy diagram.

\section{Implementasi}

Pada tahap ini adalah proses memaparkan hasil-hasil dari instalasi perangkat keras, langkah-langkah instalasi perangkat lunak, tampilan layar dan pengujian.

\section{E. Pengujian}

Pada tahap pengujian dilakukan uji coba terhadap aplikasi, kemudian hasil dari uji coba tersebut dievaluasi. Apabila terdapat kesalahan atau kekurangan pada aplikasi tersebut, maka dapat dilakukan perbaikan yang diperlukan.

\section{HASIL DAN PEMBAHASAN}

\section{A. Analisa Sistem}

Dalam pembangunan sistem ini, analisis sistem menggunakan UML. Usecase Diagram digunakan untuk menggambarkan interaksi antara aktor dengan sistem, ketika user atau pengguna menggunakan sisitem pengendali. Analisa sistem dapat dilihat pada Gambar 1.

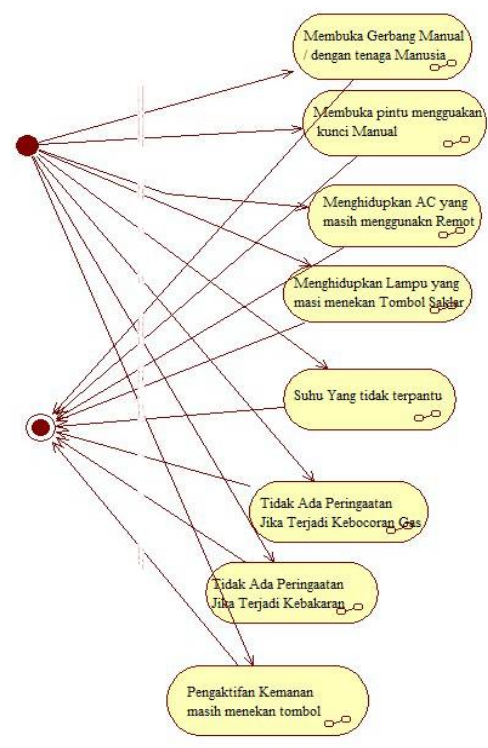

Gambar 1 Use Case Diagram Penggunaan Sistem

\section{B. Perancangan Sistem Kerja}

Dalam perancangan penggambaran cara kerja menggunakan deployment diagram dimana hal ini untuk mempermudah penelitian dalam membangun cara kerja suatu sistem. Adapun Deployment Diagram Sistem Kerja dapat dilihat pada Gambar 2. 


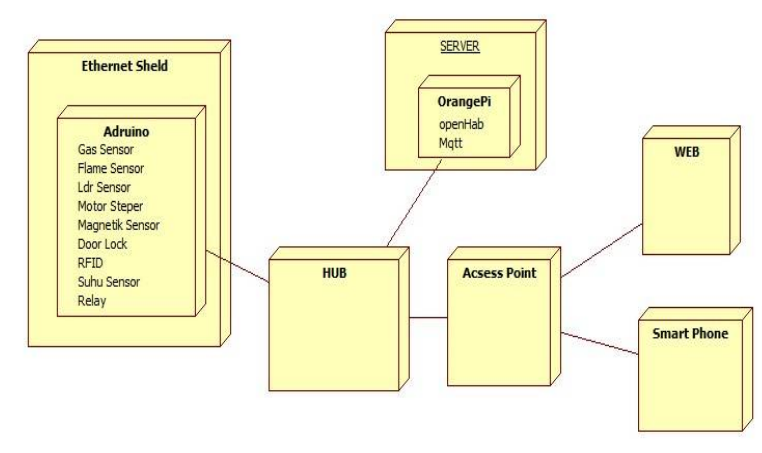

Gambar 2 Deployment Diagram Sistem Kerja

\section{Perancangan Komponen}

Tata letak dan komunikasi komponen antar komponen di gambarkan menggunakan component diagram dimana setiap jalur dan kaki-kaki pin akan terhubung dan terpusat dalam satu komponen Adapun Deployment Diagram Sistem Kerja dapat dilihat pada Gambar 3.

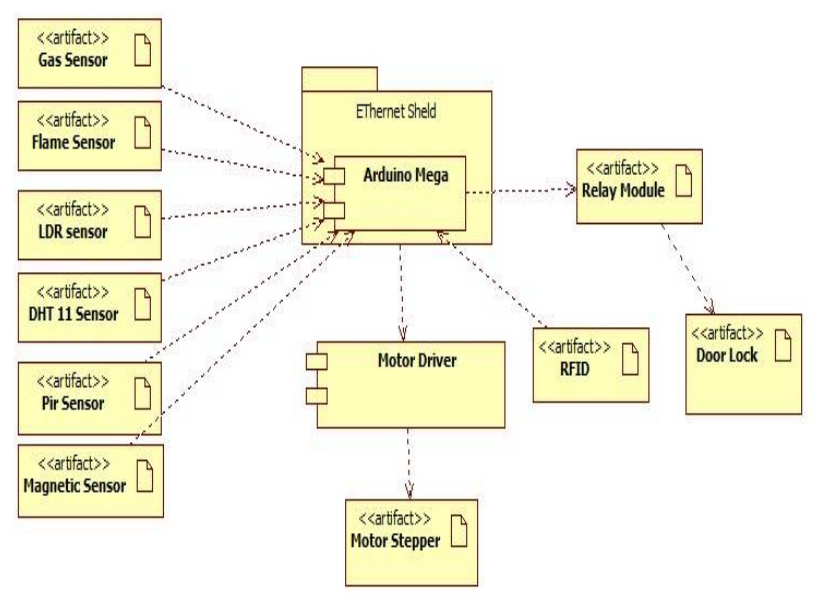

Gambar 3 Component Diagram Sistem Kerja

\section{Halaman User Interface}

Pada halaman ini user akan di permudah dengan halaman pengendali yang mudah dan user friendly.Adapun User Interface Pengguna dapat dilihat pada Gambar 4.

\section{E. Flowchart dan Algoritma Perintah Pada Arduino}

Untuk mempermudah dalam pembuatan sebuah sisitem di buat diagaram flowchart untuk mempermudah dalam pembacaan cara kerja system. Adapun Flowchart Input Perintah pada Arduino dapat dilihat pada Gambar 5.

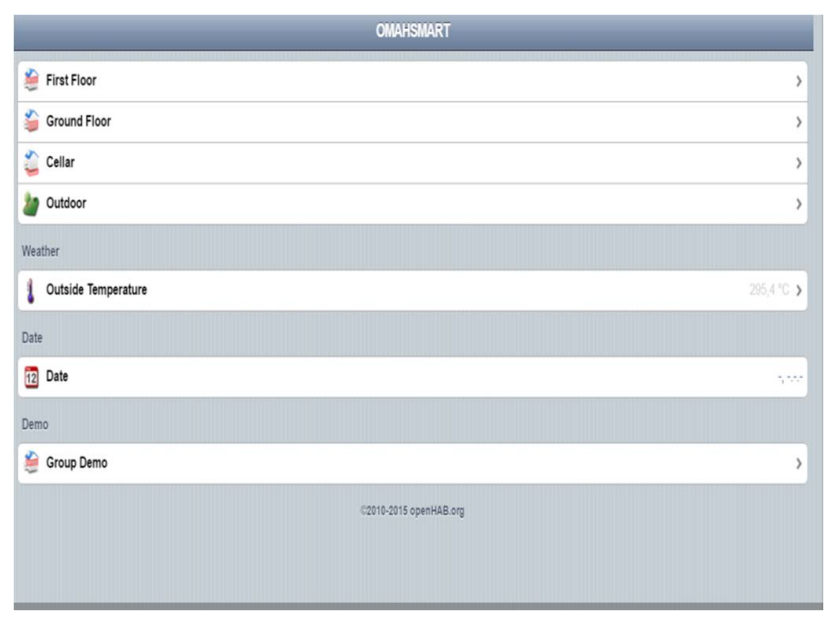

Gambar 4 User Interface Pengguna

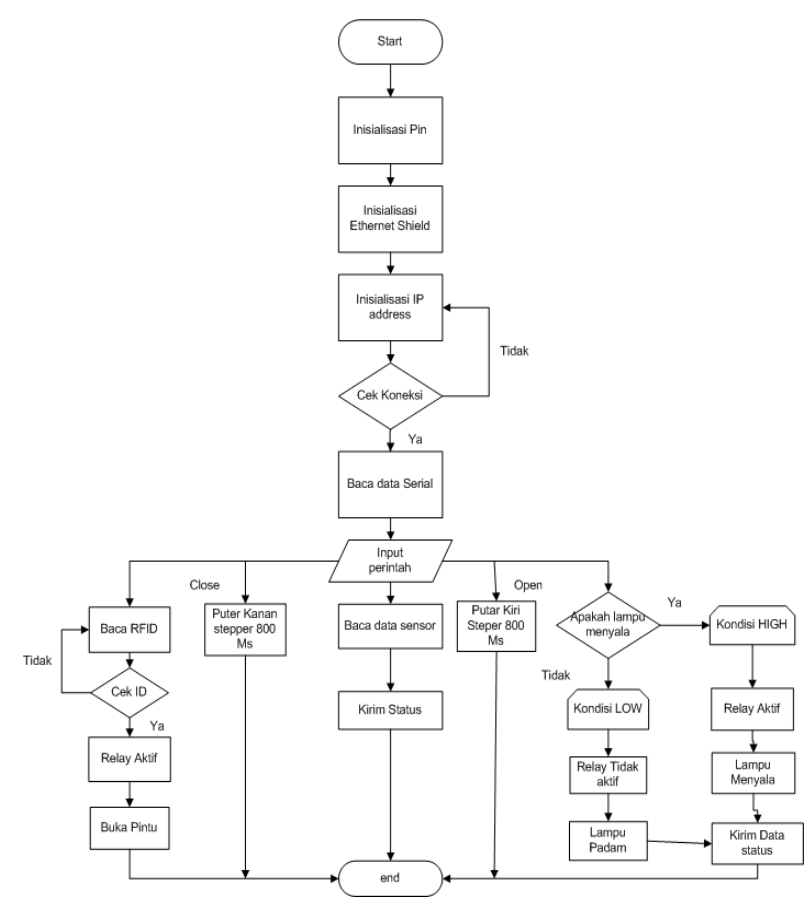

Gambar 5 Flowchart Input Perintah Pada Arduino

\section{F. Rangkaian Keseluruhan}

Pada bagian ini merupakan hasil dari rangkaian alat secara keseluruhan, dimana sudah menjadi suatu prototipe alat yang siap untuk di ujicoba. Adapun rangkaian keseluruhan dapat dilihat pada Gambar 6. 
Jurnal SISFOKOM, Volume 04, Nomor 02, September 2015

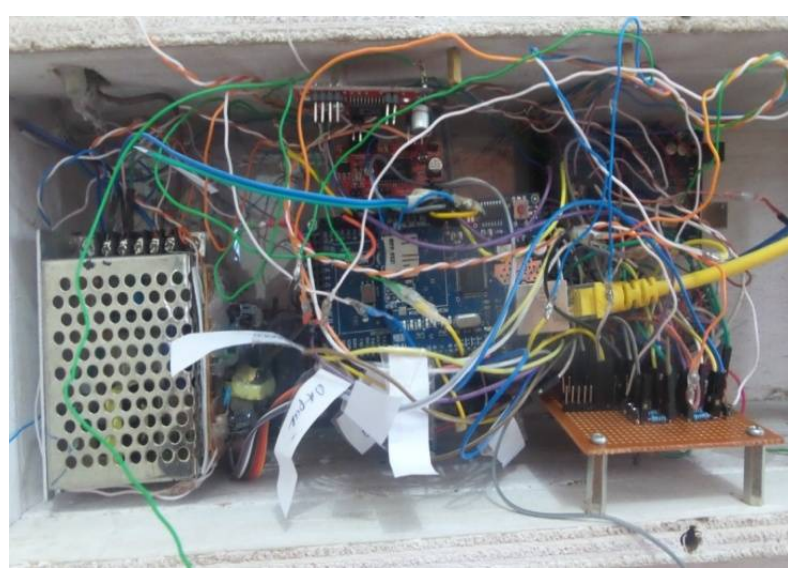

Gambar 6 Rangkaian Keseluruhan

\section{G. Tampilan Layar Kendali}

Pada bagian ini merupakan tampilan layar kendali pada webbroser dan smartphone. Tampilan layar kendali berbasis web dapat dilihat pada Gambar 7 dan tampilan layar kendali berbasis smartphone dapat dilihat pada Gambar 8.

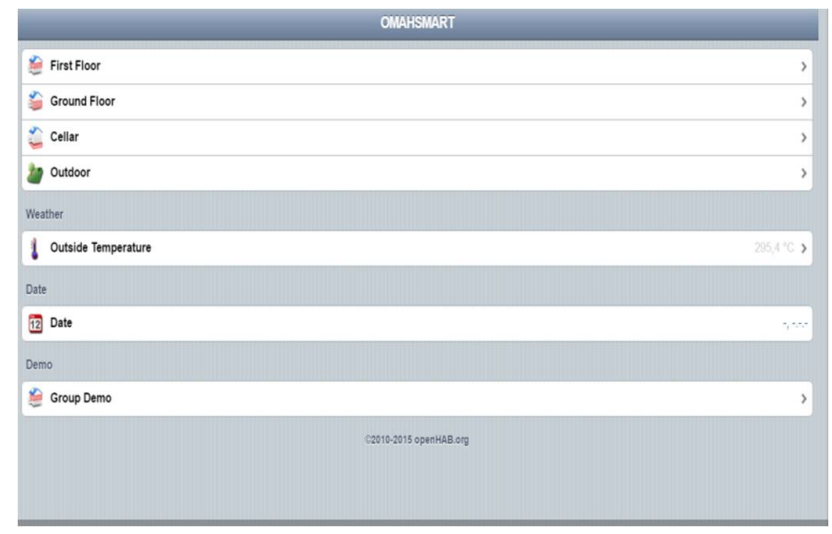

Gambar 7 Tampilan Layar Kendali Berbasis Web

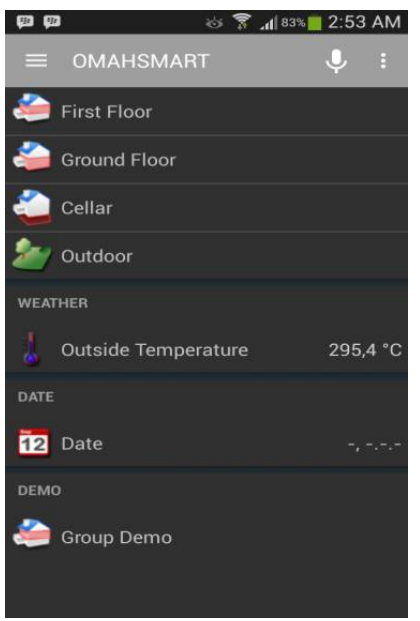

Gambar 8 Tampilan Layar Berbasis Smartphone

\section{H. Pengujian Sistem}

Pengujian sistem dimaksudkan untuk menguji semua elemen-elemen perangkat lunak yang dibuat apakah sudah sesuai dengan yang diharapkan atau belum, pengujian ini di lakukan menggunakan metode Black box, dapat dilihat pada Tabel 1

Tabel 1 Blackbox Pengujian Sensor Gas

\begin{tabular}{|c|c|c|c|c|c|}
\hline $\begin{array}{c}\mathbf{N} \\
\mathbf{0}\end{array}$ & $\begin{array}{c}\text { Deteksi } \\
\text { gas }\end{array}$ & $\begin{array}{c}\text { Status } \\
\text { Tampil }\end{array}$ & $\begin{array}{c}\text { Yang di } \\
\text { harapkan }\end{array}$ & $\begin{array}{c}\text { Pengamata } \\
\text { n }\end{array}$ & $\begin{array}{c}\text { Kesimpula } \\
\mathbf{n}\end{array}$ \\
\hline 1 & $\begin{array}{c}\text { Terdeteks } \\
\text { i Gas }\end{array}$ & $\begin{array}{c}\text { Tampilkan } \\
\text { status } \\
\text { terdeteksi } \\
\text { gas }\end{array}$ & $\begin{array}{c}\text { Tampilka } \\
\text { n gas } \\
\text { terdeteksi } \\
\text { aktifkan } \\
\text { notifikasi }\end{array}$ & $\begin{array}{c}\text { Terdeteksi } \\
\text { kebocoran } \\
\text { gas }\end{array}$ & $\begin{array}{c}{[\sqrt{ }]} \\
\text { diterima } \\
{[\text { ]ditolak }}\end{array}$ \\
\hline 2 & $\begin{array}{c}\text { Tidak ada } \\
\text { gas }\end{array}$ & $\begin{array}{c}\text { Tammpilka } \\
\text { n status } \\
\text { aman }\end{array}$ & $\begin{array}{c}\text { Notifikasi } \\
\text { not aktif }\end{array}$ & $\begin{array}{c}\text { Tidak } \\
\text { terdeteksi } \\
\text { gas }\end{array}$ & $\begin{array}{c}{[\sqrt{ }]} \\
\text { diterima } \\
{[\text { ]ditolak }}\end{array}$ \\
\hline
\end{tabular}

\section{Penutup}

Kesimpulan yang dapat diambil dari penelitian ini adalah sebagai berikut :

1. Komunikasi antara aplication control baik itu berbasis web atau mobile dengan microcontroler di lakukan secara wireless menggunkan ethenet sheld yang menghubungkan antara mikrokontroler dengan jaringan internet yang mana komunikasi antara keduanya menggunakan komunikasi data serial.

2. OpenHab merupakan salah satu aplikasi berbasis open source yang di gunakan sebagai user interface antar pengguna dan sistem dimana media penghubung antara keduaanya menggunakan mosquitto

3. Pengendalian sensor-sensor dan motor stepper menggunakan 2 bahasa pemrograman yang mana pemrograman pertama di lakukan pada epprom atau IC pada microkontroler sedangkan pengolah dan pengendali di lakukan oleh Software lain dalam hal ini OpenHab

4. Setiap perintah yang di lakukan user melalui menu interface pada openhab tidak langsung di kerjakan oleh microkontroler tetapi di terima dan oleh terlebihh dahulu oleh mosquito dan kemudian di teruskan ke open $H A B$

5. Pengendalian sensor dan prangkat lainnya harus dalam terkonekis dengan internet di karankan pengendali perangkat hanya bisa di lakukan jiak user terhubung langsung dengan sistem 


\section{DAFTAR PUSTAKA}

[1] Amperiyanto, Tri. Tips Ampuh Android. Jakarta: PT Elex Media Komputindo, 2014.

[2] Adelia, dan Jimmy Setiawan. "Implementasi Customer Relationship Management (CRM) pada Sistem Reservasi Hotel berbasisi Website dan Desktop”. Jurnal Sistem Informasi, 6 (hal.113-126), 2011.

[3] Hartono, Bambang. Sistem Informasi Manajemen Berbasis Komputer. Jakarta: PT Rineka Cipta, 2013.

[4] Rizky, Soetam. Konsep Dasar Perangkat Lunak. Jakarta : Prestasi Pustaka, 2011.

[5] Supardi, Yuniar. Sistem Operasi Andal Android. Jakarta : PT.Elex Media Komputindo, 2012.

[6] Sumardi. Mikrokontroller Belajar AVR Mulai dari Nol. Yogyakarta : Graha Ilmu, 2013.

[7] Sutabri, Tata. 2012. Konsep Dasar Informasi. Yogyakarta: Andi, 2012.

[8] Syahwil, Muhammad. Panduan Mudah Simulasi dan Praktek Mikrokontroler Arduino, 2013. 